\title{
Fire Performance of Phase Change Material Enhanced Plasterboard
}

\author{
M. S. McLaggan* (1), and R. M. Hadden, School of Engineering, University of \\ Edinburgh, Edinburgh EH9 3JL, UK \\ M. Gillie, School of Mechanical, Aerospace and Civil Engineering, University of \\ Manchester, Manchester M1 7JR, UK
}

Received: 30 July 2015/Accepted: 19 August 2017

\begin{abstract}
Sustainable construction materials are increasingly being used to reduce the carbon footprint of modern buildings. These materials have the potential to change the fire dynamics of compartments by altering the compartment energy balance however there is little quantitative understanding of how these materials behave in the event of a real fire. The changes in fire dynamics may be due to increased fuel load in a compartment, reduced time to failure or promotion of flame spread. The objective of this research is to quantify how Phase Change Materials (PCMs) perform in realistic fire scenarios. It was found that a plasterboard product containing microencapsulated PCMs will behave similarly to a charring solid and have the potential to contribute significant fuel to a compartment fire but that they maintain integrity for the duration of flaming period. The critical heat flux for this product was determined in the cone calorimeter to be $17.5 \pm 2.5 \mathrm{~kW} \mathrm{~m}^{-2}$, the peak heat release rate and mass loss rate ranged from $60.2 \mathrm{~kW} \mathrm{~m}^{-2}$ to $107 \mathrm{~kW} \mathrm{~m}^{-2}$ and $1.88 \mathrm{~g} \mathrm{~s}^{-1} \mathrm{~m}^{-2}$ to $8.47 \mathrm{~g} \mathrm{~s}^{-1} \mathrm{~m}^{-2}$ respectively for exposures between $20 \mathrm{~kW} \mathrm{~m}^{-2}$ and $70 \mathrm{~kW} \mathrm{~m}^{-2}$. Sample orientation was found to increase the peak heat release rate by up to $25 \%$, whilst having little to no effect on the mass loss rate. These parameters, in addition to the in-depth temperature evolution and ignition properties, can be used as design criteria for balancing energy savings with quantified fire performance.
\end{abstract}

Keywords: Phase change materials, Performance based design, Cone calorimeter, Flammability, Thermogravimetric analysis

\section{Introduction}

The design of buildings is a complicated multi-disciplinary process which requires the balance of many factors, including but not limited to: aesthetics, cost, function, structural stability, fire, and sustainability [1]. In recent times sustainability has become an increasingly important driving factor, with a focus on reducing the carbon footprint and achieving energy savings in the built environment. New and sophisticated novel building materials are rapidly developed to accomplish progressively more stringent sustainability goals before their fire performance can be adequately assessed [2].

* Correspondence should be addressed to: M. S. McLaggan, E-mail: martyn.scott_mclaggan@ brand.lth.se 
Phase change materials (PCMs) are a group of innovative building materials which are becoming increasingly popular because of their potential for reducing building energy consumption [3]. These materials melt during the day, thereby absorbing energy (through heat of fusion) from their surroundings and reducing the need for cooling, and then re-solidify during the evening, releasing their stored energy and reducing the need for heating. Suitable materials need to have a melting point around the intended indoor temperature, be economically viable, and have a high latent heat of fusion. The most commonly used material which fits these criteria is paraffin wax. This wax is often contained within polymer microcapsules and added into the matrix of gypsum to form a rigid wallboard or ceiling tile. Despite their usage as compartment linings there has yet to be any holistic assessment of the risk associated with this material in the event of a real fire.

Existing knowledge is based on compartment linings that are typically nonflammable given the importance of preventing fire spread between compartments [4]. Thus, the flammable nature of PCMs contained within wall linings of compartments presents a currently unquantified fire risk. With existing knowledge it is not possible for designers to quantify the effect that these materials will have on the design fire and the fuel load within the compartment.

Current standard fire test methods are useful for comparing similar materials but do not deliver adequate understanding of how the materials behave in the event of a fire to allow quantifiable fire safety performance. Therefore, it is necessary to develop test methods specifically tailored towards these new innovative materials. These methods must quantify how the material behaves in realistic fire scenarios that can be extrapolated to conditions typical of modern architecture. Quantifying the fire performance enables designers to safely incorporate these materials in buildings by understanding the associated fire risk, and balancing with the potential benefits.

In this work, commercially available plasterboard containing phase change material is characterised and the fire risk associated is quantified through testing in the cone calorimeter. This knowledge can be used to mitigate the risk associated with these materials in post-flashover fires.

\section{Flammability of Materials}

A $25 \mathrm{~mm}$ thick PCM plasterboard product has been used in this study. The core of the microencapsulated PCM is a blend of paraffin waxes, the exact composition of which is not known. The manufacturer describes the shell is as a highly cross linked polymer. The same PCM microcapsules have been studied previously using Thermogravimetric Analysis (TGA) [5]. This identified a major exothermic oxidative reaction at 199 and $233^{\circ} \mathrm{C}$ for heating rates of 1 and $5^{\circ} \mathrm{C} \mathrm{min}{ }^{-1}$ respectively. This corresponds to the core material escaping upon reaching the boiling point of the paraffin wax, and then reacting with oxygen present in air. A further series of minor exothermic oxidative reactions up to $450^{\circ} \mathrm{C}$ relates to the decomposition and pyrolysis of the polymer shell. Each of these steps also occur when the PCM is included as part of plasterboard, although some of the reactions overlap with gypsum reactions as detailed below. 


\subsection{Gypsum Plasterboard in Fire}

Gypsum, the main substrate material, undergoes two major dehydration reactions when exposed to high temperatures. In the first reaction, calcium sulphate dehydrate $\left(\mathrm{CaSO}_{4} \cdot 2 \mathrm{H}_{2} \mathrm{O}\right)$ is converted into calcium sulphate hemihydrate $\left(\mathrm{CaSO}_{4} \cdot 0.5 \mathrm{H}_{2} \mathrm{O}+1.5 \mathrm{H}_{2} \mathrm{O}\right)$, and in the second this is then converted into anhydrous calcium sulphate $\left(\mathrm{CaSO}_{4}+0.5 \mathrm{H}_{2} \mathrm{O}\right)$. These reactions overlap and occur in the range of approximately $100^{\circ} \mathrm{C}$ to $180^{\circ} \mathrm{C}$. McGraw and Mowrer [6] list the ranges as $80^{\circ} \mathrm{C}$ to $120^{\circ} \mathrm{C}$ for the first reaction, and the second reaction is complete by $200^{\circ} \mathrm{C}$. A significant amount of energy is absorbed owing to the endothermic nature of these reactions, and is an important contributor to the performance of plasterboard in fire. Decomposition of calcium carbonate is often evident within a range of $600^{\circ} \mathrm{C}$ to $700^{\circ} \mathrm{C}$. Additives may be included to improve the performance of the board for a given purpose, for example, calcite to improve sound insulation or glass fibres to improve fire performance. These will typically add further degradation steps to those listed above [7].

An abundance of literature is available on the general thermal degradation of gypsum plasterboard and its performance in standard fire tests. However, there is little data on its performance in bench-scale calorimetry, and generally the data that is available utilises plasterboard with combustible paper facings. The PCM plasterboard in this research has a non-combustible nonwoven glass fibre facing, and contains additional glass fibres throughout the core to reduce cracking. However, full details of the additives are not known.

As a comparison to ordinary gypsum board it is necessary to quantify or estimate the amount of energy released by a paper faced board. The thickness of the paper facing for a gypsum board can be modified to achieve the desired rating in the European standards system [8]. The maximum weight which will allow a B classification is $320 \mathrm{~g} \mathrm{~m}^{-2}$ [9]. The heat of combustion for the paper facing can be estimated from values of $12.7 \mathrm{MJ} \mathrm{kg}^{-1}$ for magazine paper [10], $14.1 \mathrm{MJ} \mathrm{kg}^{-1}$ for corrugated cardboard [11], or $17.5 \mathrm{MJ} \mathrm{kg}^{-1}$ for pure cellulose [12]. This leads to an upper bound limit for the amount of energy which can be produced by a paper lining as $4.2 \mathrm{MJ} \mathrm{m}^{-2}, 4.5 \mathrm{MJ} \mathrm{m}^{-2}$, or $5.6 \mathrm{MJ} \mathrm{m}^{-2}$ respectively. Additionally, Mowrer [13] has quantified the energy released from plasterboard with $220 \mathrm{~g} \mathrm{~m}^{-2}$ of paper facing, which would achieve Class A2 [9] in the European classification system. When exposed to $50 \mathrm{~kW} \mathrm{~m}{ }^{-2}$ this released $1.6 \mathrm{MJ} \mathrm{m}^{-2}$, thus deriving an effective heat of combustion of $7.2 \mathrm{~kJ} \mathrm{~g}^{-1}$.

\subsection{Thermal Analysis of PCM Plasterboard}

Simultaneous Thermogravimetric Analysis (TGA) and Differential Scanning Calorimetry (DSC) was conducted to compare the performance of the plasterboard to that reported in the literature. Heating rates of $1^{\circ} \mathrm{C} \min ^{-1}, 2.5^{\circ} \mathrm{C} \mathrm{min}-1$ and $5^{\circ} \mathrm{C} \min ^{-1}$ were used in both air and nitrogen atmospheres $\left(50 \mathrm{ml} \mathrm{min}{ }^{-1}\right.$ flow) between $50^{\circ} \mathrm{C}$ and $900^{\circ} \mathrm{C}$ (Figs. 1 and 2). Derivative mass loss to evaluate the rate of reactions is also given in Fig. 3. Samples were taken from the centre of the PCM plasterboard and found to be sufficiently homogeneous to ensure very good repeatability. In tandem with the existing TGA data of the microcapsules 

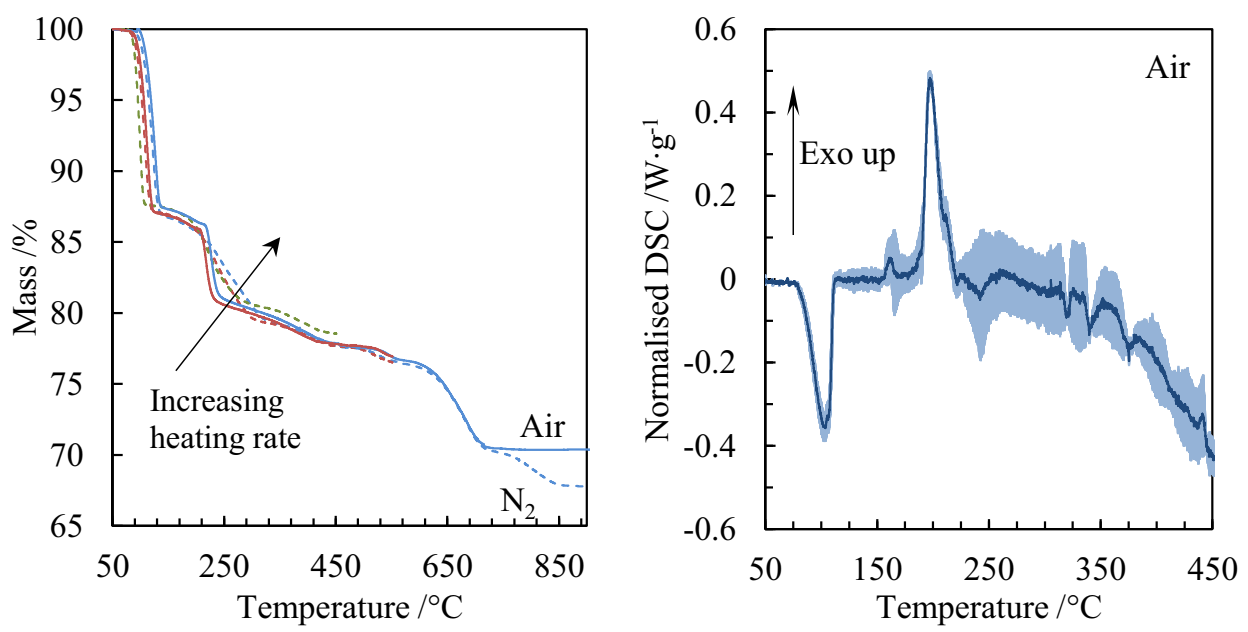

Figure 1. Mass loss rate of PCM plasterboard for heating rates of $1{ }^{\circ} \mathrm{C} \mathrm{min}{ }^{-1}, 2.5^{\circ} \mathrm{C} \mathrm{min}^{-1}$ and $5^{\circ} \mathrm{C} \mathrm{min}^{-1}$ in air (solid) and $\mathrm{N}_{2}$ (dashed), from $50^{\circ} \mathrm{C}$ to $900^{\circ} \mathrm{C}$ (leff). DSC results for PCM plasterboard for $1{ }^{\circ} \mathrm{C} \mathrm{min}^{-1}$ in air, where the shaded area indicates the standard deviation between three repeats.
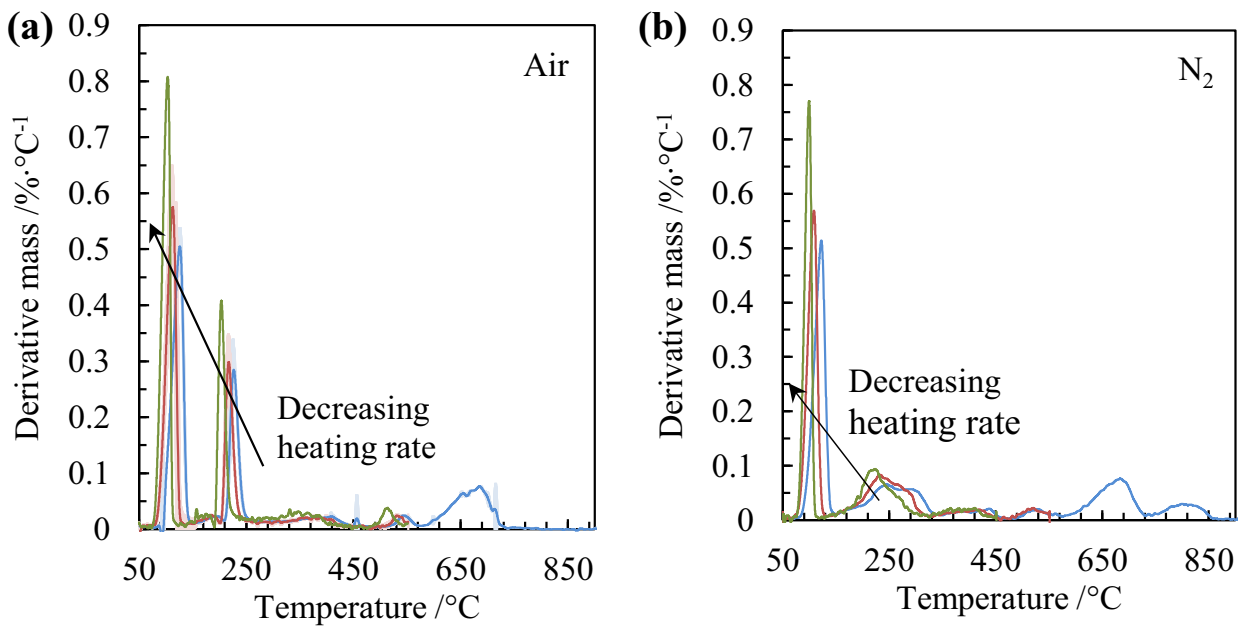

Figure 2. Derivative mass loss of PCM plasterboard for heating rates of $1{ }^{\circ} \mathrm{C} \cdot \mathrm{min}^{-1}, 2.5^{\circ} \mathrm{C} \cdot \mathrm{min}^{-1}$ and $5^{\circ} \mathrm{C} \cdot \mathrm{min}^{-1}$ from $50^{\circ} \mathrm{C}$ to $900^{\circ} \mathrm{C}$ in (a) air and (b) $\mathbf{N}_{2}$.

$[5,14]$ this provides a means to interpret the thermal degradation of integrated PCM plasterboard. More details on the experimental setup can be found elsewhere [15].

The mass loss rate confirms that the thermal degradation is a combination of the PCM and plasterboard. The endothermic dehydration reactions of gypsum are 


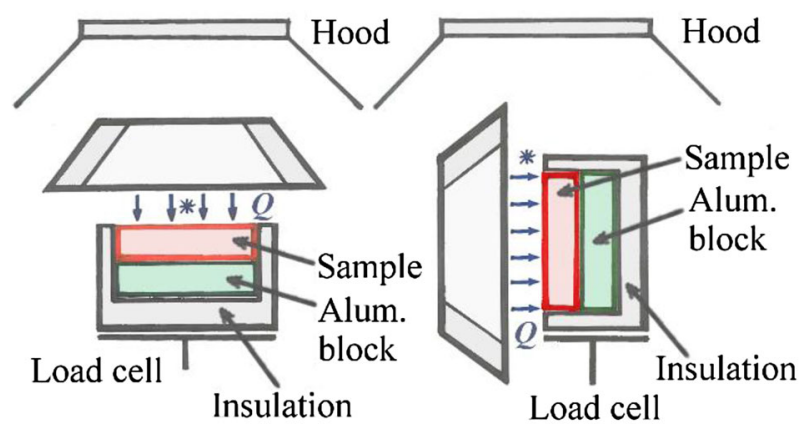

\section{Figure 3. Illustration of the (a) horizontal and (b) vertical test set- ups. The asterisk represents the position of the igniter.}

present in both air and nitrogen at $85^{\circ} \mathrm{C}$ to $150^{\circ} \mathrm{C}$, with maximum decomposition rate at $120^{\circ} \mathrm{C}$. The primary component of the PCM degradation is the evaporation and exothermic oxidation of the paraffin wax between $210^{\circ} \mathrm{C}$ and $250^{\circ} \mathrm{C}$ with peak degradation at $225^{\circ} \mathrm{C}$ (in air), similar to the peak observed previously at $233^{\circ} \mathrm{C}$ [5]. The exothermic nature of this reaction is confirmed with the DSC results. This agrees well with the testing of other microcapsules in the literature [16-20]. The moving of the exothermic peak represents only a negligible decrease in thermal stability of the PCM in plasterboard when compared to testing PCM microcapsules without the plasterboard. Other smaller degradation steps in the range of $150^{\circ} \mathrm{C}$ to $450^{\circ} \mathrm{C}$ in both air and nitrogen correspond to the pyrolysis of the PCM's polymer shell. Further degradation beyond $450^{\circ} \mathrm{C}$ are associated with the decomposition of the plasterboard since these were not observed during previous testing of the microcapsules by themselves [5]. Decomposition of the calcium carbonate occurs from $590^{\circ} \mathrm{C}$ to $735^{\circ} \mathrm{C}$, with a peak at $680^{\circ} \mathrm{C}$. The two other reactions are assumed to be associated with either additives or impurities in the gypsum $[21,22]$.

The total mass lost during the thermal degradation of the PCM is approximately $10 \%$, which is less than the $18 \%$ found for the material tested by Asimakopoulou et al. [23]. In an inert environment, the endothermic pyrolysis of the paraffin wax occurs over a higher range. Similar degradation was observed for other heating rates with peaks shifted to lower temperatures for lower heating rates.

Early testing of PCM plasterboard was done by Banu et al. in 1998 [24]. The PCM used was fundamentally different due to the encapsulation methods employed, where impregnation was achieved either by immersion in a bath of fatty acids, or addition of the PCM directly into the matrix. In recent times microencapsulation is the preferred method, and the fire performance of these methods is inherently very different. For this reason it is no longer representative of the modern PCM products found in buildings but is nonetheless a useful body of research, and represents appreciation of the fire risk associated with these materials. 
More recent testing was conducted by Asimakopoulou et al. [23] which used thermal analysis and cone calorimeter tests to characterise the behaviour of a PCM plasterboard. The thermal degradation at high heating rates was determined and the flammability was assessed. Furthermore, an attempt to model the fire behaviour using the Fire Dynamics Simulator (NIST, Gaithersburg) was made. The plasterboard was $12.5 \mathrm{~mm}$ thick and contained PCM microcapsules, but the overall product was produced by a different manufacturer. The quantity of microcapsules was estimated from TGA as $18 \%$ of the total mass, of which approximately $12 \%$ was attributed to the paraffin wax and $5 \%$ to the shell. Furthermore, the gypsum was lined with a combustible paper facing which contributed to the heat released during testing. Plasterboard with directly impregnated PCM, mentioned previously, had a total energy released of $77.75 \mathrm{MJ} \mathrm{m}^{-2}$ [24]. This suggests that the modern product is less flammable, and the burning time is much lower. The PCM content of the direct impregnation PCM was also higher, at approximately $23 \%$ plus $6 \%$ combustible paper facing, compared to approximately $10 \%$ PCM in this research. These factors combined are likely to contribute to the difference in energy released.

More recent research however found much higher flammability in which the total energy released was found to be $111.40 \mathrm{MJ} \mathrm{m}^{-2}$ at $50 \mathrm{~kW} \mathrm{~m}^{-2}$, using the standard cone calorimeter configuration [23]. Whilst this is significantly higher than the material in this research, the TGA results and flaming behaviour were also very different. This underlines the need for quantification of the fire performance of these materials as different formulations will have different burning behaviours.

\section{Experimental Approach}

The PCM plasterboard product was tested using modified cone calorimeter [25] setups, as illustrated in Fig. 3. The sample is of dimensions $100 \mathrm{~mm}$ by $100 \mathrm{~mm}$ and $25 \mathrm{~mm}$ thick wrapped in aluminium foil, and $10 \mathrm{~mm}$ of ceramic fibre insulation. A $25 \mathrm{~mm}$ thick aluminium block is placed at the rear face of the sample, before the insulation, in order to quantify the boundary condition at the back of the material $[26,27]$. The thermal conductivity of the insulation is lower than the specimens tested. Samples weighed $225.02 \pm 5.42 \mathrm{~g}$, with a density of $900.08 \pm 21.68 \mathrm{~kg} \mathrm{~m}^{-3}$. Piloted ignition tests were conducted from $70 \mathrm{~kW} \mathrm{~m}^{-2}$ until the critical heat flux was found and no flaming ignition occurred. Further testing was then done at $20 \mathrm{~kW} \mathrm{~m}^{-2}, 50 \mathrm{~kW} \mathrm{~m}^{-2}$ and $70 \mathrm{~kW} \mathrm{~m}^{-2}$ in order to characterise heat release rate (by oxygen consumption [28]), mass loss, and the temperature evolution in the material. A minimum of three specimens were tested at each heat flux between the two orientations, mass loss, and temperature measurements. For mass loss, an additional two repetitions were performed at $50 \mathrm{~kW} \mathrm{~m}^{-2}$ for the horizontal orientation and one additional repetition at

$70 \mathrm{~kW} \mathrm{~m}{ }^{-2}$ for the vertical to be able to calculate suitable error margins. A total of thirty-one specimens are presented, with a further ten specimens tested to explore boundary conditions and ensure pilot ignitor suitability. The heat flux was 

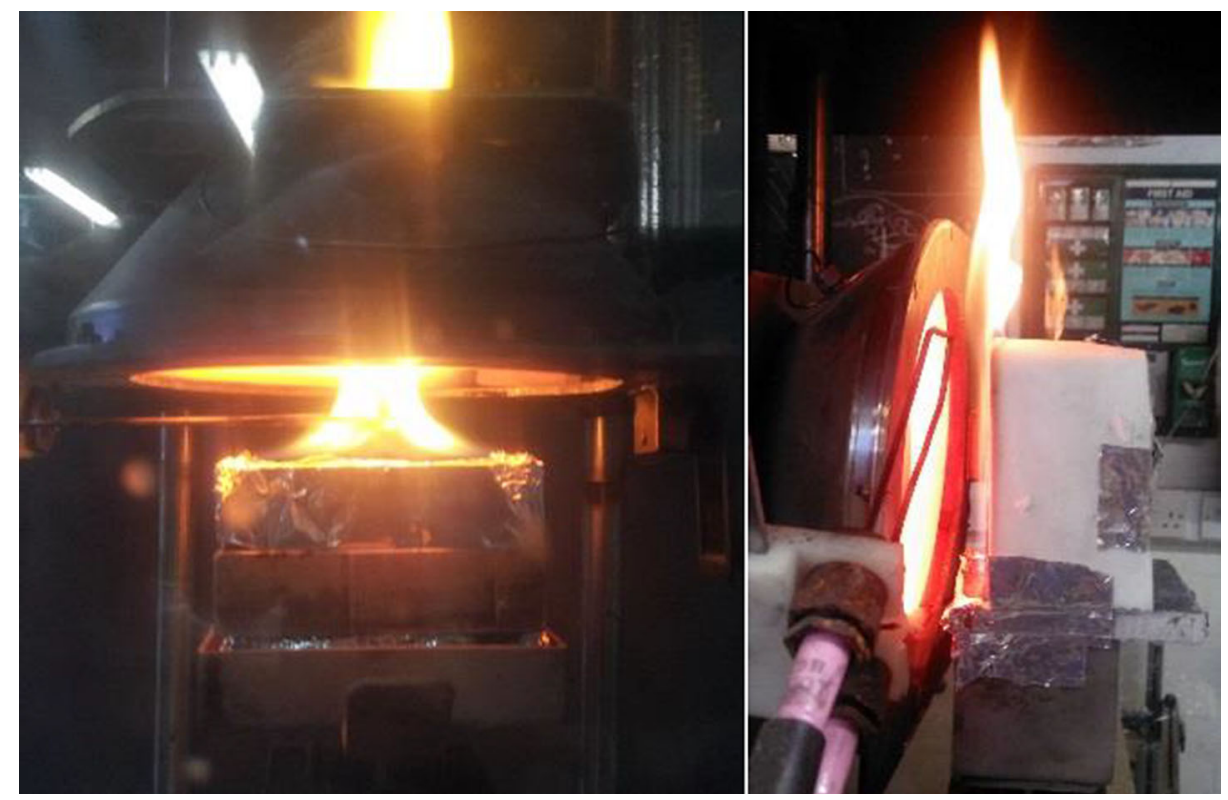

Figure 4. PCM plasterboard burning in the cone calorimeter for the two orientations. Note that in the horizontal orientation the insulation has been removed to show the aluminium block and foil for illustrative purposes only.

measured before every test using a Schmidt-Boelter gauge, and the chamber surrounding the cone heater was allowed to cool to ambient between each test.

Given their usage as wall linings and ceiling panels, samples were tested in the vertical orientation in addition to the standard horizontal orientation (Fig. 4). In the vertical orientation, a propane torch was introduced $10 \mathrm{~mm}$ away and $10 \mathrm{~mm}$ above the sample. The torch was a premixed flame $12.5 \mathrm{~mm}$ in length, and was removed upon ignition. Previous research has quantified the difference between spark and pilot flame ignition sources in the cone calorimeter. The research found that at high heat fluxes (e.g. $50 \mathrm{~kW} \mathrm{~m}^{-2}$ and $70 \mathrm{~kW} \mathrm{~m}^{-2}$ ) the ignition times for horizontal spark and vertical pilot flame were near identical for all the materials studied [29]. For low heat fluxes (e.g. $20 \mathrm{~kW} \mathrm{~m}^{-2}$ ) ignition took $10 \%$ to $55 \%$ longer with the pilot flame in the vertical orientation, dependent on the material. Typically the pilot flame reduces time to ignition by $5 \%$ to $20 \%$ due to the additional radiant heat from the flame. However, some literature indicates that at high heat fluxes the ignition time is sensitive to the pilot location [30-32].

\section{Results and Discussion}

A summary of the results for each of the heat fluxes and orientations can be found in Table 1. The critical heat flux was independent of the orientation and 


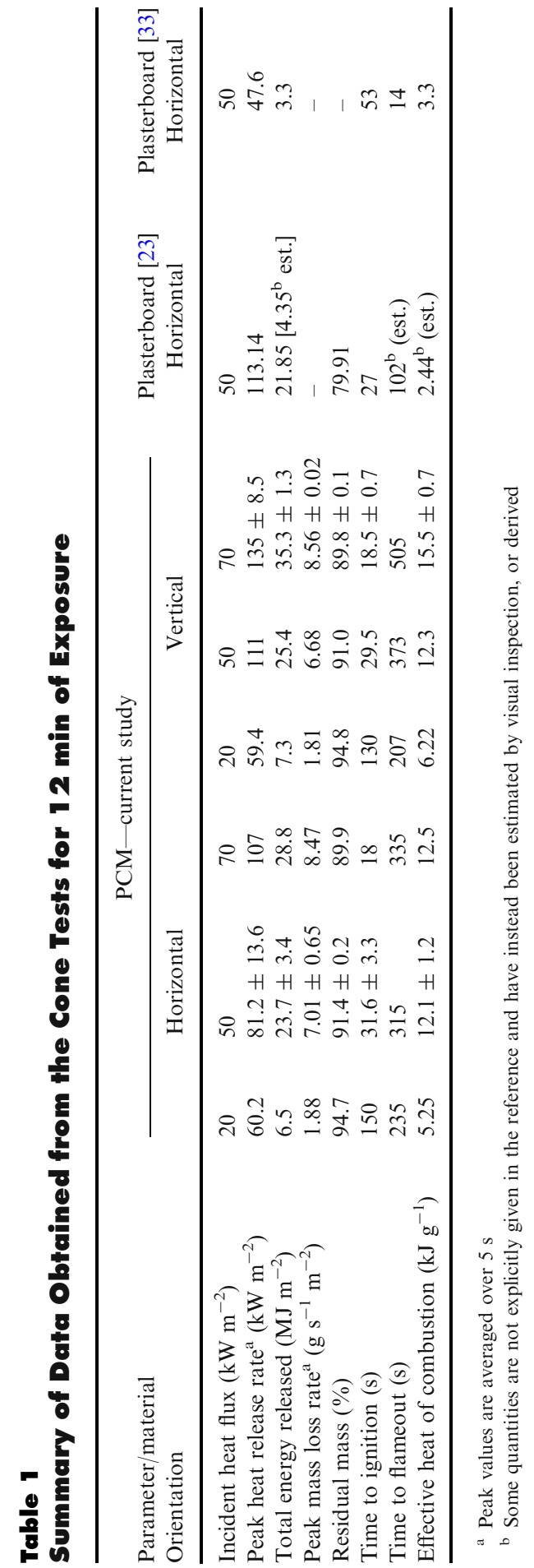




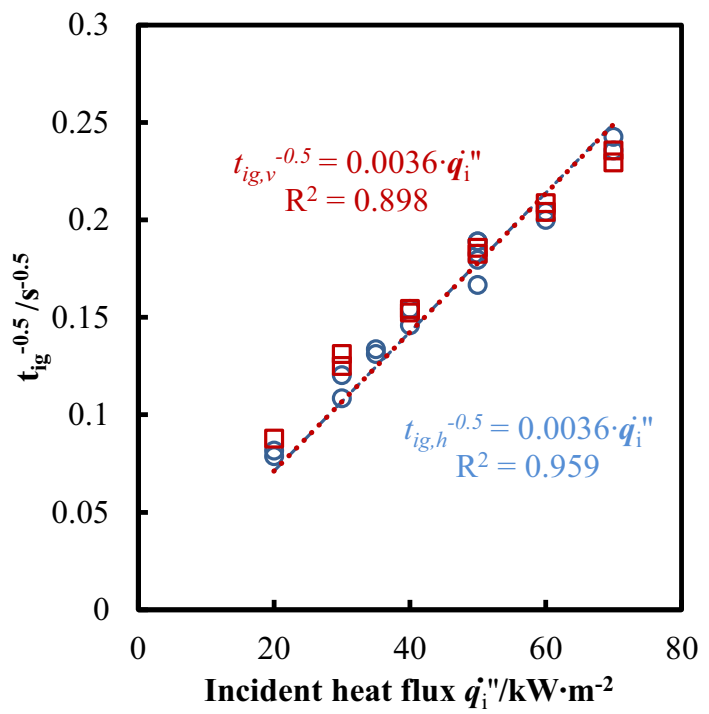

\section{Figure 5. Time to ignition data of PCM plasterboard plotted as inci- dent radiant heat flux $\dot{q}_{i}^{\prime \prime}$ against $t_{i g}^{-0.5}$. Blue circles represent horizon- tal orientation (h), whilst red squares represent the vertical orientation (v) (Color figure online).}

found to be $17.5 \pm 2.5 \mathrm{~kW} \mathrm{~m}^{-2}$. The $1 / \sqrt{ } t_{i g}$ versus incident heat flux plot (Fig. 5) shows good agreement with classic ignition theory for a thermally thick solid [32] across the range of heat fluxes, where $t_{i g}$ represents the time to ignition.

Upon exposure to the external radiant heat flux the surface of the material heats up to the first and second dehydration reactions of the gypsum, and driving off the water contained in the specimen. The endothermic nature of these reactions delays the increase in temperature further, and hence postpones ignition. The temperature then increases to the pyrolysis temperature of the PCM, and the paraffin wax contained within is able to escape and mix with air above the sample. This corroborates well with previous work [23] which analysed the remnants of tested microcapsules using a Scanning Electron Microscope (SEM) and confirmed that the paraffin wax was able to escape from the capsules. Once sufficient volume of plasterboard has reached the pyrolysis temperature, the mass flux of the pyrolysis products exceeds the critical value and ignition occurs at the pilot.

Specimens were removed after 12 min of testing to maintain consistent exposure, except where thermocouples were present in which case the test duration matched the time taken for the temperatures to reach a steady state, as detailed below. For all heat fluxes, the introduction of ambient air causes rapid cooling of the surface and minor cracking is observed. These were a maximum of $1 \mathrm{~mm}$ wide. The cracking for these exposure times did not seem significant thus no substantial investigation was taken into their size, formation or distribution. Cracking is commonly the source of failure in furnaces or fires for ordinary gypsum and thus a significant body of research has been done to evaluate it. Literature relating 


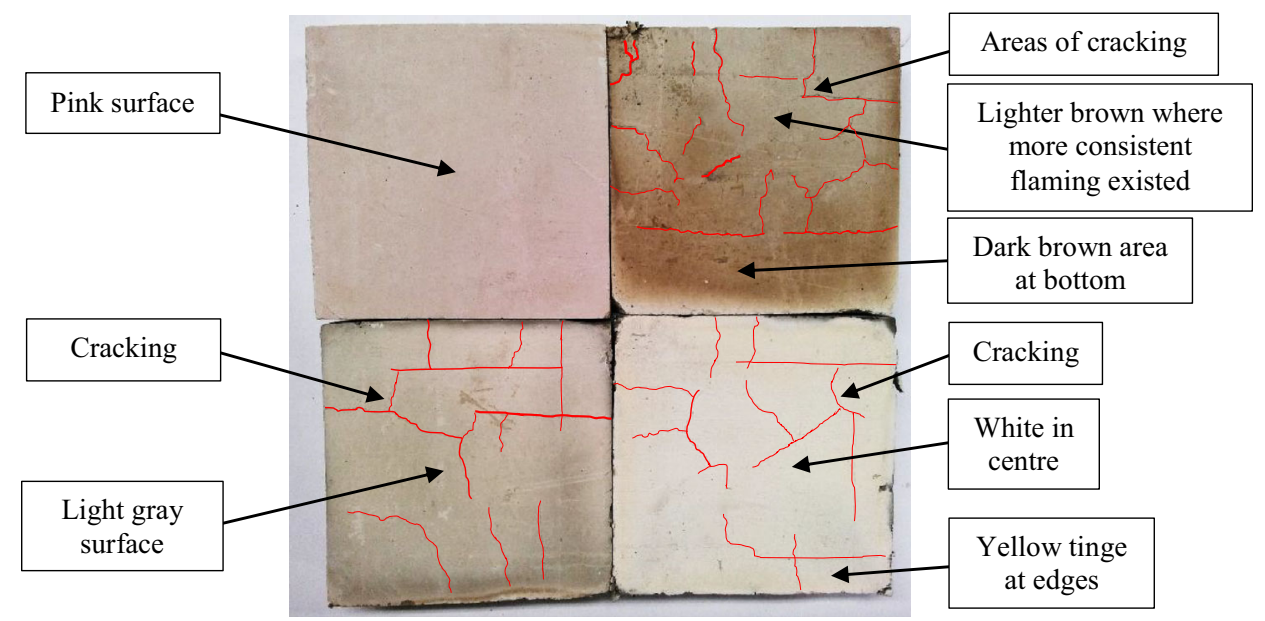

\section{Figure 6. PCM plasterboard: before testing (top left), after testing, $20 \mathrm{~kW} \mathrm{~m}^{-2}$ in vertical (top right), after $50 \mathrm{~kW} \mathrm{~m}^{-2}$ in vertical (bot- fom left), and after $70 \mathrm{~kW} \mathrm{~m}^{-2}$ in horizontal (botfom right).}

cracking depth to the external radiant flux, or total energy absorbed, is available and provides a potential path forward for future study [34].

The surface of the sample exposed to $20 \mathrm{~kW} \mathrm{~m}^{-2}$ or below has a browned or blackened surface, with some area of gray (Fig. 6b). In the $50 \mathrm{~kW} \mathrm{~m}^{-2}$ the surface is a white or light gray (Fig. 6c), whilst in the $70 \mathrm{~kW} \mathrm{~m}^{-2}$ the surface is similar but is brighter and has a tinge of yellow (Fig. 6d). The discolouration at the highest heat flux may represent thermal decomposition at temperatures not reached in the other tests. However, it is not possible to confirm this without knowledge of the exact gypsum composition.

\subsection{Thermal Evolution}

The temperature histories through the thickness of a specimen exposed to $50 \mathrm{~kW} \mathrm{~m}^{-2}$ are given in Fig. 7. Three thermocouples were placed at depths of $4 \mathrm{~mm}, 12 \mathrm{~mm}$ and $20 \mathrm{~mm}$ from the surface, and three within the aluminium block to indicate the temperature of the rear face, although these all record the same temperature due to the thermal properties of the block. The cone heater remained on for the duration of the experiment. Three of the major degradation steps found from TGA earlier (Fig. 1) have been marked. Thermal degradation steps of $85^{\circ} \mathrm{C}$ to $150^{\circ} \mathrm{C}, 210^{\circ} \mathrm{C}$ to $250^{\circ} \mathrm{C}$, and $590^{\circ} \mathrm{C}$ to $735^{\circ} \mathrm{C}$ represent, respectively, (I) both dehydration reactions of the gypsum, (II) the major exothermic oxidative reaction of the paraffin wax, and (III) decomposition of the calcium carbonate in the gypsum. The effect of the dehydration reactions of gypsum can be seen, particularly at a depth of $20 \mathrm{~mm}$ as the absorbed heat flux is lowest. Close to the surface the temperature increases rapidly and little time is required to drive off the entirety of the water. 


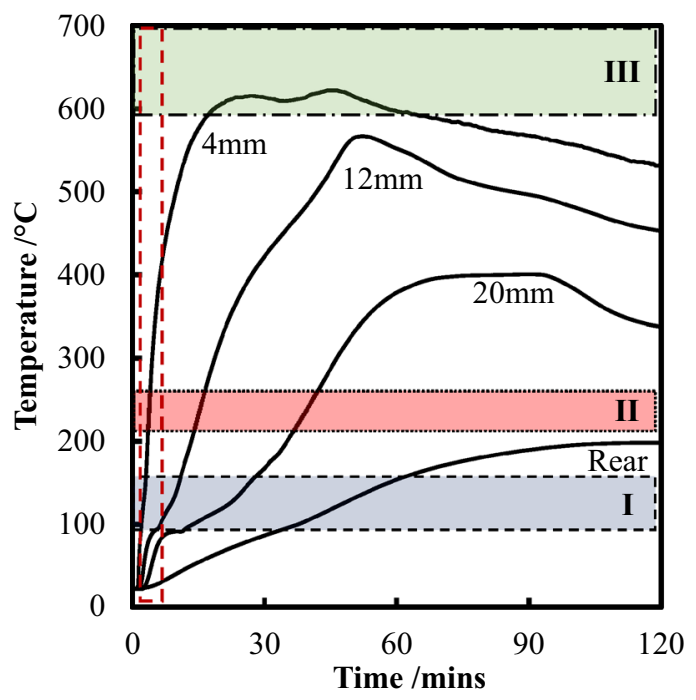

Figure 7. Temperature profiles through sample exposed to $50 \mathrm{~kW} \mathrm{~m}^{-2}$ in the horizontal orientation. (1) Dehydration of gypsum. (II) Oxidation of paraffin wax (III). Decomposition of calcium carbonate. Temperatures continued to decrease until 180 min but are not shown. Vertical red dashed lines signify duration of flaming (Color figure online).

It can be seen that at least $20 \mathrm{~mm}$ of the sample reaches the evaporation temperature of the PCM - after around $40 \mathrm{~min}$-indicating that the total fuel load of PCM will contribute to a fire. The final $5 \mathrm{~mm}$, evident between $20 \mathrm{~mm}$ and the rear in the Figure, approaches this temperature point but due to heat losses to the aluminium block it is not reached. The maximum temperature reached is $630^{\circ} \mathrm{C}$ at $4 \mathrm{~mm}$ from the surface, and would expected to be higher at the surface where it is closer to the external radiant heat flux from the cone, and flaming on the surface. This may be high enough for the thermal decomposition of calcium carbonate.

Data on the temperature evolution can be used to calculate the heat flux through the sample as a future part of a fire risk assessment. This will allow the designer to identify the thermal penetration time, temperature of the back face and the amount of material which will undergo pyrolysis. The presence of the aluminium block at the back surface of the specimen will increase the time taken for the thermal wave to reach the back when compared to insulation. Thus, the results will be more onerous. This can be used to identify the currently unquantified change in fire dynamics represented by the addition of PCMs.

In Fig. 8 the in-depth temperatures of the specimen at various time intervals are shown. This illustrates the evolution of the heat transfer through the material over time. The temperature evolution between both Figs. 7 and 8 suggest additional energy generation at temperatures above the oxidation of the PCM. This is evident from the fact that there is more than one peak, and the temperature decrea- 


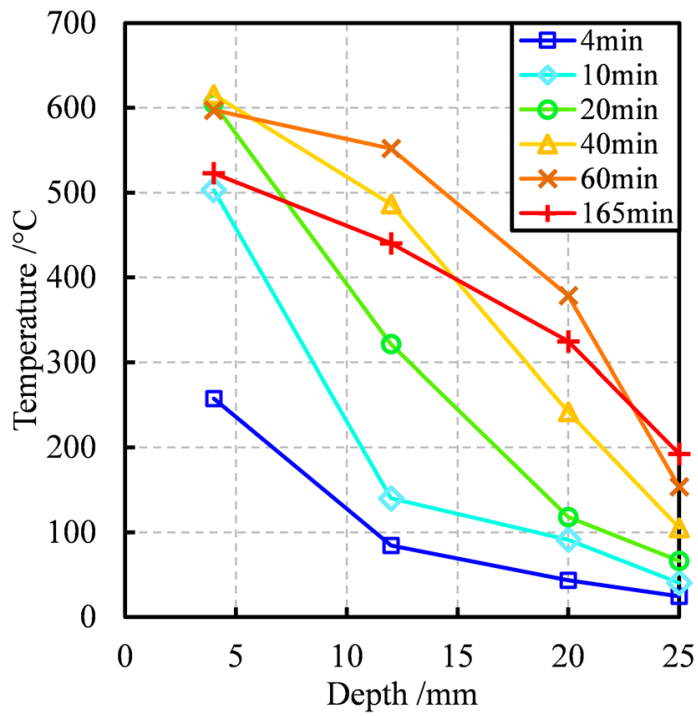

\section{Figure 8. Temperature gradient through sample exposed to $50 \mathrm{~kW} \mathrm{~m}^{-2}$. The legend provides, in minutes, the time of each tem- perature versus depth slice.}

ses to the steady state. This period of elevated temperature above the steady state values is far greater than duration of flaming. For this reason is it believed that additional radiation from flaming is not the cause, but there is insufficient information to be able to identify the source of energy for certain.

\subsection{Mass Loss and Heat Release}

From Fig. 9 it can be seen that the material behaves similarly to a charring solid, and thus the peak of both mass loss rate (MLR) and heat release rate (HRR) are reached shortly after ignition. As evaporation and pyrolysis proceeds a char-like layer will develop which will inhibit both heat and mass transfer to the solid phase in-depth [32]. The cause of this behaviour hypothesised to be due to change the change in thermal properties of the gypsum which reduces its thermal conductivity and density, and increases the permeability. The change of properties are due to the loss of moisture, as well as a change in the crystalline structure of gypsum at higher temperatures [35]. The heat wave penetrates through the specimen but the temperature distribution arising from the low thermal inertia of the plasterboard means that fewer PCM vapours are generated. The reduction of heat transfer to the reaction front causes the MLR and HRR to decay over time. As the flow of flammable gases reduces, a pulsing blue flame is observed on the surface, suggesting lean combustion of the pyrolysis products and evaporated wax. Eventually insufficient vapours will be generated to maintain the pulsing flame and extinction will occur. Mass will continue to be lost due the dehydration and decomposition of the gypsum as well as pyrolysis of the PCM shell and evaporation of the paraffin wax, but without ignition. In the case of the $20 \mathrm{~kW} \mathrm{~m}^{-2}$ tests 

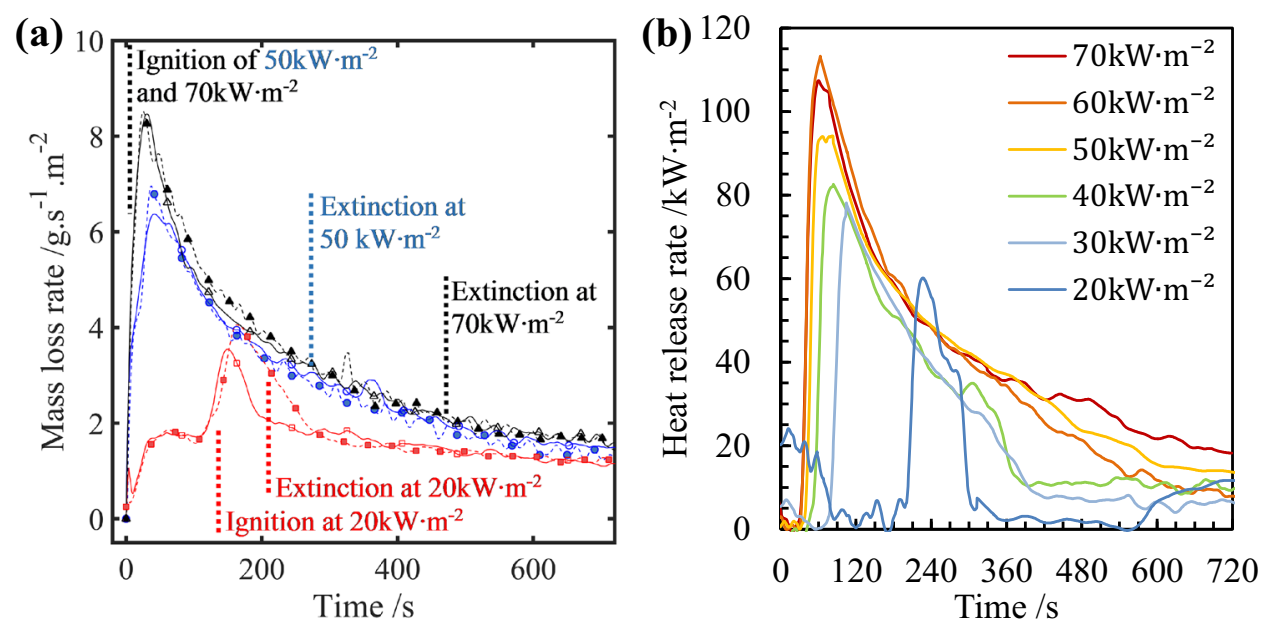

\section{Figure 9. (a) Mass loss rate of three heat fluxes (i) $20 \mathrm{~kW} \mathrm{~m}^{-2}$, red squares (ii) $50 \mathrm{~kW} \mathrm{~m}^{-2}$, blue circles (iii) $70 \mathrm{~kW} \mathrm{~m}^{-2}$, black triangles. Filled symbols represent vertical orientation, and hollow represent horizontal. (b) Heat release rate over time for every $10 \mathrm{~kW} \mathrm{~m}^{-2}$ from $70 \mathrm{~kW} \mathrm{~m}^{-2}$ (dark red) down to $20 \mathrm{~kW} \mathrm{~m}^{-2}$ (dark blue) in horizontal orientation (Color figure online).}

mass lost due to evaporation, pyrolysis and dehydration is clearly visible both before ignition $(0 \mathrm{~s}$ to $140 \pm 10 \mathrm{~s})$ and after ignition $(221 \pm 14 \mathrm{~s}$ to end $)$.

An increase in the incident heat flux increases the magnitude of the peak mass loss rate, and both reduces the time to ignition and the time taken to reach the peak mass loss rate. This behaviour is also observed in charring solids. Following the loss of moisture and change of the crystalline structure of the gypsum, the mass loss rate then tends to an asymptotical value of approximately $1.75 \mathrm{~g} \mathrm{~s}^{-1} \mathrm{~m}^{-2}$ and has reduced dependence on the incident heat flux. This is due to a reduction in the heat transfer rate from the cone heater through this char-like layer to the virgin material below.

The heat release rate over time (Fig. 9b) shows a similar trend to the mass loss rate typical of a material which behaves as a charring solid. This is fundamentally different from paper faced gypsum where a short, sharp peak [23, 33, 36] of similar magnitude is observed (confer with Table 1). After this period there is no further contribution to the fire load and the dehydration reactions of the gypsum are able to reduce the rate of heat transfer through the wall. In the case of PCM enhanced plasterboard there are still pyrolysis gases generated through the duration of the test as the material reaches the pyrolysis temperature in-depth. The net result is that the total energy released by PCM-enhanced gypsum is substantially higher $\left(23.7 \pm 3.4 \mathrm{MJ} \mathrm{m}^{-2}\right.$ for PCM compared to $1.6-5.6 \mathrm{MJ} \mathrm{m}^{-2}$ for plasterboard products, discussed in Sect. 2). This illustrates that the fire risk associated with ordinary plasterboard is not identical to PCM-enhanced plasterboards. Thus, 


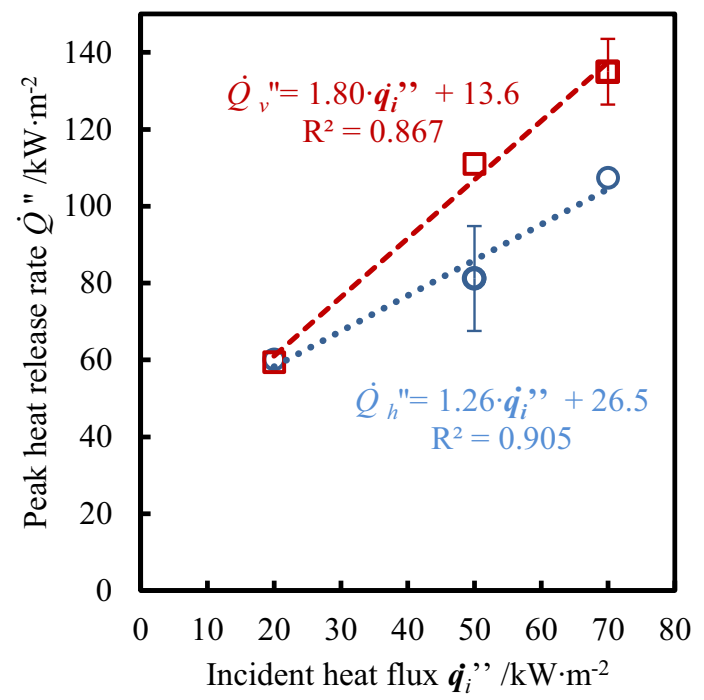

\section{Figure 10. Peak HRR $\boldsymbol{Q}^{\prime \prime}$ for different external heat fluxes, for hori- zontal (blue circles, dotfed trendline) and vertical orientations (red squares, dashed trendline) (Color figure online).}

the total energy released becomes a more fitting metric than simply the peak heat release rate.

\subsection{Effect of Sample Orientation}

It is known that the sample orientation will affect the time to ignition and HRR of a combustible material when the same ignition source is used in both orientations [37]. The similarity in results of time to ignition for horizontal and vertical match those found in a previous study [29]. The variance of peak HRR against incident heat flux for both orientations is shown in Fig. 10. Typically the HRR is found to be $10 \%$ higher in the vertical which is believed to be due to the differences in surrounding environment, air entrainment, and the feedback from the flame [37]. However, the exact effect of each of these is not known. For this material peak HRR is found to be up to $25 \%$ higher at $70 \mathrm{~kW} \mathrm{~m}^{-2}$, but with little change at the lowest incident heat flux.

It is evident from Fig. 9 that there is no such increase in MLR, despite the increase in HRR. Previous research also noted that the magnitude of mass loss was independent of orientation [38]. However, in the same research the time to ignition was found to be shorter in the vertical orientation than horizontal, which contradicts other literature $[29,37,39,40]$. In the other literature the mass loss rates are not given so no comparison can be drawn.

The vertical orientation more closely represents the usage of this material as a wall lining, which also gives the higher HRR. Furthermore, smaller error margins were recorded for all parameters in the vertical instead of the horizontal. This again may be due to the different conditions in the vertical orientation but no 
quantification is available in the literature. It may be pertinent for designers to consider whether vertical results are more relevant than the widely used horizontal. The material studied does not experience any of the common issues with the vertical orientation, for example, there is no dripping, melting, expanding or contracting.

\section{Conclusions}

A quantification of the fire risk associated with a commercially available PCM plasterboard product has been carried out. This has identified the critical heat flux, mass loss rate, heat release rate, time to ignition and temperature evolution of the product at various relevant heat fluxes. It was found that these materials will behave similarly to charring solids and have the potential to contribute significant fuel to a compartment fire but that they maintain integrity for the duration of flaming period. Using TGA and bench-scale test methods the key steps in the chemical decomposition processes have been identified as the dehydration of gypsum between $85^{\circ} \mathrm{C}$ and $150^{\circ} \mathrm{C}$, oxidation of paraffin wax between $210^{\circ} \mathrm{C}$ and $250^{\circ} \mathrm{C}$, and the decomposition of calcium carbonate between $590^{\circ} \mathrm{C}$ and $735^{\circ} \mathrm{C}$. This represents the most complete study of these materials thus far and a useful tool in evaluating the fire risk associated.

This quantification of the fire risk can be used by designers for compartments containing PCMs subjected to a fully developed fire. Using the critical heat flux, heat release per unit area and mass loss rate will allow the contribution to a fire to be quantified and for the fire risk associated with these materials to be mitigated.

Future work could involve larger scale testing to validate the results of this study, characterising the heat flux through the specimen to understand the potential for fire spread through the wall, or the investigation of cracking which is integral to the performance of ordinary plasterboard.

\section{Acknowledgements}

The authors gratefully acknowledge the support of a joint BRE Trust and EPSRC award to the primary author.

\section{Open Access}

This article is distributed under the terms of the Creative Commons Attribution 4.0 International License (http://creativecommons.org/licenses/by/4.0/), which permits unrestricted use, distribution, and reproduction in any medium, provided you give appropriate credit to the original author(s) and the source, provide a link to the Creative Commons license, and indicate if changes were made. 


\section{References}

1. Law M (1986) Translation of research into practice: building design. Fire Saf Sci 1:603-609. doi:10.3801/IAFSS.FSS.1-603

2. Torero JL (2013) Scaling-up fire. Proc Combust Inst 34:99-124. doi:10.1016/ j.proci.2012.09.007

3. Kuznik F, David D, Johannes K, Roux J-J (2011) A review on phase change materials integrated in building walls. Renew Sustain Energy Rev 15:379-391. doi:10.1016/ j.rser.2010.08.019

4. Harmathy TZ (1979) Effect of the nature of fuel on the characteristics of fully developed compartment fires. Fire Mater 3:49-60. doi:10.1002/fam.810030109

5. McLaggan MS, Hadden RM, Gillie M (2015) Smouldering combustion of phase change materials within a porous hemp matrix. In: Ninth Mediterranean combustion symposium

6. McGraw J, Mowrer F (2000) Flammability and dehydration of painted gypsum wallboard subjected to fire heat fluxes. Fire Saf Sci 6:1003-1014. doi:10.3801/IAFSS.FSS.61003

7. Janssens M (2011) Thermogravimetric study of dehydration and thermal degradation of gypsum board at elevated temperatures. Fire Saf Sci 10:295-306. doi:10.3801/ IAFSS.FSS.10-295

8. British Standards Institution (2009) BS EN 13501-1:2007+A1: 2009 Fire classification of construction products and building elements - part 1: classification using data from reaction to fire tests. BSI, London

9. British Standards Institution (2009) BS EN 520:2004+A1: 2009 Gypsum plasterboards - definitions, requirements and test methods. BSI, London

10. SFPE (2016) Appendix 3: Fuel properties and combustion data. In: Hurley MJ, Gottuk DT, Hall JR Jr, Harada K, Kuligowski ED, Puchovsky M, Torero JL, Watts JM Jr, Wieczorek CJ (eds) SFPE handbook of fire protection engineering, 5th edn. Springer, $p$ 3448

11. Xin Y, Khan MM (2007) Flammability of combustible materials in reduced oxygen environment. Fire Saf J 42:536-547. doi:10.1016/j.firesaf.2007.04.003

12. Jessup RS, Prosen EJ (1950) Heats of combustion and formation of cellulose and nitrocellulose (cellulose nitrate). J Res Natl Inst Stan 44:387-393

13. Mowrer FW (2004) Flammability of oil-based painted gypsum wallboard subjected to fire heat fluxes. Fire Mater 28:355-385. doi:10.1002/fam.832

14. McLaggan MS, Hadden RM, Gillie M (2017) Flammability assessment of phase change material wall lining and insulation materials with different weight fractions. Energy Build . doi:10.1016/j.enbuild.2017.08.012(in Press)

15. McLaggan MS (2016) Novel fire testing frameworks for phase change materials and hemp-lime insulation. http://hdl.handle.net/1842/15896

16. Zhang H, Wang X (2009) Synthesis and properties of microencapsulated $n$-octadecane with polyurea shells containing different soft segments for heat energy storage and thermal regulation. Sol Energy Mater Sol Cells 93:1366-1376. doi:10.1016/j.solmat.2009. 02.021

17. Zhang H, Sun S, Wang X, Wu D (2011) Fabrication of microencapsulated phase change materials based on $n$-octadecane core and silica shell through interfacial polycondensation. Colloids Surf A Physicochem Eng Asp 389:104-117. doi:10.1016/j.colsurfa.2011. 08.043 
18. Qiu X, Li W, Song G et al (2012) Fabrication and characterization of microencapsulated $n$-octadecane with different crosslinked methylmethacrylate-based polymer shells. Sol Energy Mater Sol Cells 98:283-293. doi:10.1016/j.solmat.2011.11.018

19. Fang G, Chen Z, Li H (2010) Synthesis and properties of microencapsulated paraffin composites with $\mathrm{SiO}_{2}$ shell as thermal energy storage materials. Chem Eng J 163:154159. doi:10.1016/j.cej.2010.07.054

20. Alkan C, Sari A, Karaipekli A (2011) Preparation, thermal properties and thermal reliability of microencapsulated n-eicosane as novel phase change material for thermal energy storage. Energy Convers Manage 52:687-692. doi:10.1016/j.enconman.2010. 07.047

21. Yu QL, Brouwers HJH (2012) Thermal properties and microstructure of gypsum board and its dehydration products: a theoretical and experimental investigation. Fire Mater 36:575-589. doi:10.1002/fam.1117

22. Ghazi Wakili K, Hugi E (2009) Four types of gypsum plaster boards and their thermophysical properties under fire condition. J Fire Sci 27:27-43. doi:10.1177/0734904108094514

23. Asimakopoulou EK, Kolaitis DI, Founti MA (2015) Fire safety aspects of PCM-enhanced gypsum plasterboards: an experimental and numerical investigation. Fire Saf J 72:50-58. doi:10.1016/j.firesaf.2015.02.004

24. Banu D, Feldman D, Hawes D (1998) Evaluation of thermal storage as latent heat in phase change material wallboard by differential scanning calorimetry and large scale thermal testing. Thermochim Acta 317:39-45. doi:10.1061/(ASCE)0899-1561(1998)10:2(98)

25. Babrauskas V (1984) Development of the cone calorimeter-a bench-scale heat release rate apparatus based on oxygen consumption. Fire Mater 8:81-95

26. Carvel R, Steinhaus T, Rein G, Torero JL (2011) Determination of the flammability properties of polymeric materials: a novel method. Polym Degrad Stab 96:314-319. doi:10.1016/j.polymdegradstab.2010.08.010

27. Reszka P (2008) In-depth temperature profiles in pyrolyzing wood. University of Edinburgh, Edinburgh

28. Janssens ML (1991) Measuring rate of heat release by oxygen consumption. Fire Technol 27:234-249. doi:10.1007/BF01038449

29. Shields TJ, Silcock GW, Murray JJ (1993) The effects of geometry and ignition mode on ignition times obtained using a cone calorimeter and ISO ignitability apparatus. Fire Mater 17:25-32

30. Moysey EB, Muir WE (1968) Pilot ignition of building materials by radiation. Fire Technol 4:46-50. doi:10.1007/BF02588605

31. Janssens M (1991) Piloted ignition of wood: a review. Fire Mater 15:151-167. doi:10.1002/fam.810150402

32. Torero JL (2016) Flaming ignition of solid fuels. SFPE handbook of fire protection engineering Springer, New York, NY, pp 633-661

33. Chew M, Lim SM (2000) The impact of wall linings on fire hazard. Int J Archit Sci 1:96-107

34. DeHaan JD, Icove DJ (2012) Kirk's fire investigation, 7th edn. Pearson Education, Cranbury, NJ

35. Lázaro D, Puente E, Lázaro M et al (2015) Thermal modelling of gypsum plasterboard assemblies exposed to standard fire tests. Fire Mater. doi:10.1002/fam.2311

36. Mowrer F, Williamson R (1991) Flame spread evaluation for thin interior finish materials. Fire Saf Sci 3:689-698. doi:10.3801/IAFSS.FSS.3-689

37. Tsai KC (2009) Orientation effect on cone calorimeter test results to assess fire hazard of materials. J Hazard Mater 172:763-772. doi:10.1016/j.jhazmat.2009.07.061 
38. Yang L, Wang Y, Zhou X et al (2012) Experimental and numerical study of the effect of sample orientation on the pyrolysis and ignition of wood slabs exposed to radiation. J Fire Sci 30:211-223. doi:10.1177/0734904111429272

39. Babrauskas V, Parker W (1987) Ignitability measurements with the cone calorimeter. Fire Mater 11:31-43

40. Fangrat J, Hasemi Y, Yoshida M, Hirata T (1996) Surface temperature at ignition of wooden based slabs. Fire Saf J 27:249-259. doi:10.1016/S0379-7112(96)00046-X 